\title{
Cytisine induces apoptosis of HepG2 cells
}

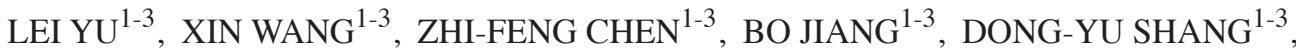 \\ YONG-XUE SUN ${ }^{1-3}$, JING-HUI YANG ${ }^{1-3}$, LIAN-FANG ZHANG ${ }^{1-3}$ and YU-BIN JI ${ }^{1-3}$ \\ ${ }^{1}$ Center of Research and Development on Life Sciences and Environmental Sciences; ${ }^{2}$ Institute of Materia \\ Medica and Postdoctoral Program, Harbin University of Commerce; ${ }^{3}$ Engineering Research Center of \\ Natural Anticancer Drugs, Ministry of Education, Harbin, Heilongjiang 150076, P.R. China
}

Received March 27, 2016; Accepted March 3, 2017

DOI: $10.3892 / \mathrm{mmr} .2017 .6991$

\begin{abstract}
Cytisine is a quinolizidine alkaloid, which has been reported to be among the major bioactive components of Sophora alopecuraides L. Quinolizidine alkaloids have previously been demonstrated to inhibit the proliferation of several types of tumor cells. However, few studies have investigated the effects of cytisine on cancer cells. The present study was performed to further investigate the molecular mechanisms underlying cytisine-induced apoptosis of HepG2 human hepatocellular carcinoma cells. The results of an MTT assay demonstrated that cytisine inhibited the growth of HepG2 cells in a dose-dependent manner. In addition, the induction of apoptosis was detected, as determined by morphological observation and flow cytometry. As determined by fluorescence microscopy, apoptotic morphological alterations were detected following cytisine administration. Flow cytometric analyses demonstrated that cytisine induced cytotoxicity through apoptosis-like mechanisms in HepG2 cells. Furthermore, western blot analysis was performed to investigate the release of cytochrome $c(\mathrm{Cyt}-\mathrm{c})$ and activation of the caspase cascade, and the results indicated that treatment of HepG2 cells with cytisine induced caspase-dependent apoptosis via the release of Cyt-c from the mitochondria, upregulation of caspase- 3 and downregulation of pro-caspase- 3 . These results indicated that cytisine may induce apoptosis of HepG2 cells through the mitochondrial pathway.
\end{abstract}

\section{Introduction}

Cancer is among the primary causes of mortality in developing and developed countries, and is therefore considered a global concern. An increasing number of cases of cancer and

Correspondence to: Dr Lei Yu, Center of Research and Development on Life Sciences and Environmental Sciences, Harbin University of Commerce, 138 Tongda Street, Harbin, Heilongjiang 150076, P.R. China

E-mail: yulei912@163.com

Key words: cytisine, HepG2 cells, apoptosis, mitochondrial membrane potential, mitochondrial pathway cancer-associated mortality are projected to occur worldwide. An analysis of the available anticancer drugs revealed that the majority of approved anticancer drugs are unmodified natural products or their semisynthetic derivatives, or molecules synthesized based on natural product compound pharmacophores (1). Natural products are considered a promising source for future drugs (2). It has previously been demonstrated that aloperine, oxymatrine, sophoridine and cytisine exert antitumor effects, with some having important roles in cancer treatment (3). Aloperine has previously been demonstrated to exhibit anti-inflammatory properties in vitro and in vivo (4). In addition, aloperine was able to significantly induce apoptosis of SW480 and HCT116 human colon cancer cells (5). Previous studies have indicated that oxymatrine exhibits activity against hepatic fibrosis (6). Furthermore, sophoridine exerts various pharmacological activities, including anticancer effects, and selectively induces apoptotic cell death of various human cancer cell types in vitro and in vivo (7). The effects of sophoridine have also been determined on the induction of apoptosis of human glioma U87MG cells, revealing that sophoridine increased apoptosis in these cells (8). Cytisine is a naturally occurring quinolizidine alkaloid with antitumor activities $(9,10)$. Cytisine has been used as a nicotine receptor partial agonist that may improve the success of smoking cessation by maintaining moderate levels of dopamine, which counteracts withdrawal symptoms, and reducing the satisfaction associated with smoking (11). However, although the application of cytisine increased the likelihood of an individual quitting smoking, absolute quit rates were modest. Nicotinic acetylcholine receptors (nAChRs) are pharmacological targets that are thought to be involved in the reinforcing effects associated with various drugs of abuse (12). Cytisine is a nAChR partial agonist that is currently in clinical use as a smoking cessation aid. Previous studies have conducted radio-ligand displacement experiments to characterize cytisine with regards to its binding affinity for heteromeric nAChRs, using membrane preparations from cells stably expressing human nAChRs (13-15). Cytisine has also been used for the treatment of central nervous system diseases; it has previously been demonstrated that cytisine may significantly inhibit N-methyl-D aspartate receptor exposure-induced neuronal apoptosis by reversing intracellular $\mathrm{Ca}^{2+}$ overload and balancing the expression levels of B-cell lymphoma 2 (Bcl-2) and $\mathrm{Bcl}-2$-associated $\mathrm{X}$ protein (16). Furthermore, novel pharmacological and antitumor activities 
of cytisine have previously been identified. Cytisine has been demonstrated to inhibit the proliferation of A549, HepG2, Ec109, K562, HL-60 and U937 cells (3). In K562 cells and the esophageal carcinoma cell line Ec109, as in other tumor cell lines, marked cytisine-induced inhibition of proliferation was detected; however, the specific mechanism of action remains to be elucidated (17).

Hepatocellular carcinoma (HCC) is considered to be the third leading cause of all cancer-associated mortalities and the fifth most common cancer type worldwide. There are a number of different treatment strategies for HCC, including liver transplantation, ablation, resection, chemotherapy and embolization, however, patient prognosis remains poor. It is therefore necessary to develop specific drugs and treatment strategies for HCC (18). The present study investigated the molecular mechanisms underlying cytisine-induced apoptosis of human HepG2 cells. In addition, the mitochondrial proapoptotic effects of cytisine on HepG2 cells were examined, with regards to loss of mitochondrial membrane potential, cytochrome $c(\mathrm{Cyt}-\mathrm{c})$ release into the cytosol and altered expression of components of the caspase cascade.

\section{Materials and methods}

Instruments and reagents. Cytisine was purchased from Shaanxi River Pharmaceutical Co., Ltd. (Xi'an, China). 10-hydroxycamptothecin (HCPT) was purchased from Aladdin Reagent Co., Ltd (Shanghai, China). The HepG2 human hepatocellular carcinoma cell line was obtained from the Center of Research and Development on Life Sciences and Environmental Sciences, Harbin University of Commerce (Harbin, China). MTT was purchased from Beijing Solarbio Science \& Technology Co., Ltd. (Beijing, China). RPMI-1640 medium was purchased from Gibco; Thermo Fisher Scientific, Inc. (Waltham, MA, USA). Fetal calf serum (FCS) was obtained from Hyclone; GE Healthcare Life Sciences (Logan, UT, USA). Hoechst 33258 stain and propidium iodide (PI) were obtained from Beyotime Institute of Biotechnology (Haimen, China). Cell lysis buffer for western blotting and immunoprecipitation (IP) was also purchased from Beyotime Institute of Biotechnology (cat. no. P0013). $\beta$-actin, Cyt-c and caspase-3 monoclonal antibodies were purchased from Santa Cruz Biotechnology, Inc. (Dallas, TX, USA). The EPICS $\mathrm{XL}^{-M_{C} \mathrm{~L}^{\mathrm{TM}}}$ flow cytometer was purchased from Beckman Coulter, Inc. (Brea, CA, USA) and the fluorescence microscope was obtained from Olympus Corporation (Tokyo, Japan).

MTT assay. The viability of HepG2 cells following treatment was determined by measuring the reduction of soluble MTT to water insoluble formazan $(19,20)$. HepG2 cells were cultured in RPMI-1640 with $12 \%$ FCS. HepG2 cells were seeded at a density of $5 \times 10^{4} / \mathrm{ml} /$ well in a volume of $100 \mu \mathrm{l}$ in 96 -well plates and cultured at $37^{\circ} \mathrm{C}$ with $5 \% \mathrm{CO}_{2}$ for $24 \mathrm{~h}$ prior to being used in the cell viability assay. Cells were treated with cytisine at the following concentrations: $1.5,3,6,12$ and $24 \mathrm{mmol} \cdot \mathrm{l}^{-1}$, or with positive drug HCPT (Aladdin Reagent Co., Ltd.) at 0.1, 1, 10 and $100 \mu \mathrm{mol} \cdot 1^{-1}$ for $72 \mathrm{~h}$ at $37^{\circ} \mathrm{C}$. Cytisine and HCPT belong to the same family of alkaloids, thus HCPT was used as positive drug in the present study to verify that the experimental method was correct. Subsequently, $20 \mu 1 \mathrm{MTT}$ was added to each well, and the cells were incubated for an additional $3 \mathrm{~h}$ at $37^{\circ} \mathrm{C}$. Dimethyl sulfoxide $(100 \mu \mathrm{l})$ was then added to each well to dissolve the formazan crystals and absorbance was read at a wavelength of $570 \mathrm{~nm}$ using a microplate reader. The inhibition (\%) of cell viability was determined as follows: Viability inhibition $=$ [optical density of control cells-optical density of treated cells)/optical density of control cells] x100. All observations were validated by at least three independent experiments.

Nuclear staining with Hoechst 33258. The nuclear morphology of cytisine-treated HepG2 cells was examined to determine the effect of cytisine on apoptosis. Nuclear morphology was evaluated using membrane-permeable blue Hoechst 33258. Briefly, HepG2 cells were plated on a 6 -well $\left(1 \mathrm{ml} \cdot \mathrm{well}^{-1}\right)$ microplate at a density of $3 \times 10^{5} / \mathrm{ml}$ and cultured at $37^{\circ} \mathrm{C}$ and $5 \% \mathrm{CO}_{2}$. Cytisine $\left(2.5,5\right.$ and $\left.10 \mathrm{mmol} \cdot \mathrm{l}^{-1}\right)$ or $60 \mu \mathrm{mol} \cdot \mathrm{l}^{-1} \mathrm{HCPT}$ was added to the cells and the plate was incubated at $37^{\circ} \mathrm{C}$ in a humidified atmosphere containing $5 \% \mathrm{CO}_{2}$ for $48 \mathrm{~h}$. HepG2 cells were then fixed with $800 \mu 14 \%$ (w/v) paraformaldehyde in PBS for $1 \mathrm{~h}$ at $4^{\circ} \mathrm{C}$. For staining, the cells were washed twice with PBS and stained with Hoechst 33258 at room temperature in the dark for $30 \mathrm{~min}$. The cells were subsequently examined and images were captured under a fluorescence microscope (21-23).

Apoptosis assays. Quantitative analysis of apoptosis was performed by flow cytometry with PI staining $(24,25)$. HepG2 cells were plated on a 6 -well $\left(1 \mathrm{ml} \cdot \mathrm{well}^{-1}\right)$ microplate at a density of $3 \times 10^{5} / \mathrm{ml}$ and cultured for $24 \mathrm{~h}$ at $37^{\circ} \mathrm{C}$ and $5 \% \mathrm{CO}_{2}$. HepG2 cells were exposed to cytisine $\left(2.5,5\right.$ and $\left.10 \mathrm{mmol} \cdot \mathrm{l}^{-1}\right)$ or $60 \mu \mathrm{mol} \cdot 1^{-1} \mathrm{HCPT}$ for $48 \mathrm{~h}$ in culture media at $37^{\circ} \mathrm{C}$ in an atmosphere containing $5 \% \mathrm{CO}_{2}$. Cells were gently harvested following trypsin digestion and washed twice with PBS. The cells were subsequently centrifuged at $833 \mathrm{x}$ g for $10 \mathrm{~min}$ at room temperature. Cells $\left(1 \times 10^{6}\right)$ were formed into a single cell suspension with PBS solution and fixed with $70 \%$ ice-cold ethanol at $4^{\circ} \mathrm{C}$ overnight. Subsequently, cells were washed twice with PBS, then permeabilized and stained with a solution containing $800 \mu \mathrm{l}$ PI (PI staining solution: Sodium citrate $33.4 \mathrm{mg}$, PI $5 \mathrm{mg}$, RNaseA $1 \mathrm{mg}$ and Trtiton-X-100 $0.5 \mathrm{ml}$ ) for $30 \mathrm{~min}$ in the dark at room temperature. The stained cells were detected by flow cytometry (EPICS XL-MCL; Beckman Coulter, Inc.) and analyzed by MultiCycle for Windows 32-bit software (Beckman Coulter, Inc.) (26). The aim of this process was to reveal the apoptotic cells by analyzing the results of the PI and Hochest 33258 staining collectively.

Measurement of mitochondrial membrane potential. Cells were treated with cytisine $\left(2.5,5\right.$ and $\left.10 \mathrm{mmol} \cdot \mathrm{l}^{-1}\right)$ or HCPT $\left(60 \mu \mathrm{mol} \cdot \cdot^{-1}\right)$ for $24 \mathrm{~h}$. Subsequently, $3 \times 10^{5}$ cells were collected and suspended in rhodamine 123 dye $\left(10 \mu \mathrm{g} \cdot \mathrm{ml}^{-1}\right)$ at $37^{\circ} \mathrm{C}$ for $30 \mathrm{~min}$ in the dark $(27,28)$. The cells were washed with PBS twice, and fluorescence intensity was determined by flow cytometry (EPICS XL-MCL; Beckman Coulter, Inc.) at $525 \mathrm{~nm}$ emission wavelength. The data was analyzed using EXPO32 ${ }^{\mathrm{TM}}$ ADC software (Beckman Coulter, Inc).

Western blot analysis. HepG2 cells were harvested following treatment with cytisine $\left(2.5,5\right.$ and $\left.10 \mathrm{mmol}^{-1}\right)$ or HCPT 
Table I. Inhibition of HepG2 cell viability by cytisine, as determined by MTT assay.

\begin{tabular}{lccc}
\hline Group & Optical density & $\mathrm{IR}(\%)$ & $\mathrm{IC}_{50}$ \\
\hline Control & $1.77 \pm 0.07$ & $\mathrm{NA}$ & $\mathrm{NA}$ \\
Cytisine, $\mathrm{mmol} \cdot \mathrm{l}^{-1}$ & & & $5.36 \mathrm{mmol} \cdot \mathrm{l}^{-1}$ \\
1.5 & $1.42 \pm 0.07^{\mathrm{a}}$ & 19.77 & \\
3.0 & $1.23 \pm 0.08^{\mathrm{a}}$ & 30.51 & \\
6.0 & $0.83 \pm 0.04^{\mathrm{a}}$ & 53.11 & \\
12.0 & $0.43 \pm 0.04^{\mathrm{a}}$ & 75.71 & \\
24.0 & $0.29 \pm 0.04^{\mathrm{a}}$ & 84.18 & \\
$\mathrm{HCPT}, \mu \mathrm{mol} \cdot \mathrm{l}^{-1}$ & & & $8.56 \mu \mathrm{mol} \cdot \mathrm{l}^{-1}$ \\
0.1 & $1.36 \pm 0.05^{\mathrm{a}}$ & 23.60 & \\
1 & $1.14 \pm 0.12^{\mathrm{a}}$ & 37.08 & \\
10.0 & $0.88 \pm 0.04^{\mathrm{a}}$ & 48.31 & \\
100.0 & $0.75 \pm 0.03^{\mathrm{a}}$ & 57.87 & \\
\end{tabular}

Results are presented as the mean \pm standard deviation, $n=3 .{ }^{\mathrm{a}} \mathrm{P}<0.01$ vs. control. IR, inhibition rate; $\mathrm{IC}_{50}$, half maximal inhibitory concentration; NA, not applicable; HCPT, 10-hydroxycamptothecin.

$\left(60 \mu \mathrm{mol} \cdot \mathrm{l}^{-1}\right)$ for $24 \mathrm{~h}$ at $37^{\circ} \mathrm{C}$ and $5 \% \mathrm{CO}_{2}$. Whole cellular proteins were extracted and cytosolic fractions were prepared, according to the procedure described by the manufacturer of cell lysis buffer for western blotting and IP (cat. no. P0013; Beyotime Institute of Biotechnology). Protein concentrations were quantified using the bicinchoninic acid method. After boiling for $10 \mathrm{~min}, 50 \mu \mathrm{g}$ protein was loaded onto a $15 \%$ SDS-PAGE gel and run at $80 \mathrm{~V}$ for $30 \mathrm{~min}$ and $120 \mathrm{~V}$ for $1 \mathrm{~h}$. Proteins were transferred onto nitrocellulose membranes. After incubation for $1 \mathrm{~h}$ in blocking solution (5\% nonfat dry milk in $20 \mathrm{mM}$ of TBS with $0.1 \%$ Tween) at room temperature, the membrane was incubated for $24 \mathrm{~h}$ with Cyt-c (1:200; cat. no. SC-13156, ZSGB Bio Co., Ltd.), caspase-3 (1:500; cat. no. SC-7148; ZSGB Bio Co., Ltd., Beijing, China), pro-caspase-3 (1:500; cat. no. TA336455; ZSGB Bio Co., Ltd.) and $\beta$-actin (1:1,000; cat. no. TA-09; ZSGB Bio Co., Ltd.) primary antibodies at $4^{\circ} \mathrm{C}$. The secondary antibodies, such as Peroxidase-Conjugated AffiniPure Goat Anti-Rabbit IgG [heavy + light chain (H+L); 1:5,000; cat. no. ZB-2301; ZSGB Bio Co., Ltd.] and Peroxidase-Conjugated AffiniPure Goat Anti-Mouse IgG (H+L; 1:5,000; cat. no. ZB-2305; ZSGB Bio Co., Ltd.) were added at a 1:5,000 dilution and the membranes were incubated at room temperature for $2 \mathrm{~h}$. Membranes were visualized with 3,3'-diaminobenzidine (cat. no. K145911; ZSGB Bio Co., Ltd.). Images were captured using a GIS-2019 Tanon Gel Imaging system (Tanon Science \& Technology Co., Ltd., Shanghai, China) and hybrid bands were semi-quantitatively analyzed using Gel-Pro Analyzer 3.1 (Tannon gel imaging system GIS-2019; Tanon Science \& Technology Co., Ltd.) density analysis software (29).

Statistical analysis. The results are presented as the mean \pm standard deviation and three experimental repeats were conducted. Differences among groups were analyzed using one-way analysis of variance and multiple comparisons
Table II. Apoptotic rate of HepG2 cells, as determined by flow cytometry.

\begin{tabular}{lcc}
\hline Group & Number of cells & Apoptotic rate, $\%$ \\
\hline Control & $1 \times 10^{5}$ & $1.39 \pm 0.62$ \\
Cytisine, $\mathrm{mmol}^{-1} \mathrm{l}^{-1}$ & & \\
2.5 & $1 \times 10^{5}$ & $17.14 \pm 0.49^{\mathrm{a}}$ \\
5.0 & $1 \times 10^{5}$ & $73.32 \pm 4.42^{\mathrm{a}}$ \\
10.0 & $1 \times 10^{5}$ & $90.74 \pm 2.33^{\mathrm{a}}$ \\
$\mathrm{HCPT}, \mu \mathrm{mol} \cdot \mathrm{l}^{-1}$ & & \\
60.0 & $1 \times 10^{5}$ & $13.83 \pm 3.16^{\mathrm{a}}$ \\
\hline
\end{tabular}

Results are presented as the mean \pm standard deviation, $n=3 .{ }^{a} \mathrm{P}<0.01$ vs. control. HCPT, 10-hydroxycamptothecin.

were performed using the Student-Newman-Keuls method. Statistical analysis was performed using SPSS 19.0 software (IBM SPSS, Armonk, NY, USA). P<0.01 was considered to indicate a statistically significant difference.

\section{Results}

Cytisine inhibits cell viability and increases HepG2 cell death. HepG2 cells were exposed to various concentrations of cytisine or HCPT for $72 \mathrm{~h}$ and cytotoxicity was determined by MTT assays. As presented in Table I cytisine reduced HepG2 cell viability in vitro in a dose-dependent manner. The half maximal inhibitory concentration $\left(\mathrm{IC}_{50}\right)$ of cytisine was $5.36 \mathrm{mmol} \cdot \mathrm{l}^{-1}$, whereas the $\mathrm{IC}_{50}$ value of HCPT was $8.56 \mu \mathrm{mol} \cdot 1^{-1}$.

Morphological investigation. As shown in Fig. 1, Hoechst 33258 fluorescence photomicrographs of cultured HepG2 cells treated with cytisine or HCPT, and control cells, were captured. In control cultures, the nuclei of the HepG2 cells were round, large in size and exhibited regular contours (Fig. 1A). The number of HepG2 cells with smaller nuclei and condensed chromatin was limited. Conversely, the majority of nuclei in cytisine-treated HepG2 cells (Fig. 1B-D) were hypercondensed (brightly stained). The number of apoptotic nuclei containing condensed chromatin increased as the result of increased concentration. Some treated cells exhibited formation of apoptotic bodies, which were visible as round or oval masses of cytoplasm with multifragmented nuclei. When HepG2 cells were treated with $60 \mu \mathrm{mol} / 1$ HCPT, a number of apoptosis-associated morphologies were detected including chromatin condensation, marginalization of apoptotic cells and nuclear membrane lysis. In addition, chromatin was divided into blocks and typical apoptotic bodies (Fig. 1E).

Apoptotic analysis. Apoptotic rates were analyzed using PI staining and flow cytometric analysis. The results demonstrated that cytisine is capable of inducing apoptosis at concentrations of 2.5 and $5 \mathrm{mmol} \cdot \mathrm{l}^{-1}(17.14 \pm 0.49$ and $73.32 \pm 4.42 \%$, respectively). Cytisine induced the highest percentage of apoptosis at $10 \mathrm{mmol}^{-1}(90.74 \pm 2.33 \%)$ compared with the control $(\mathrm{P}<0.01$; 
A

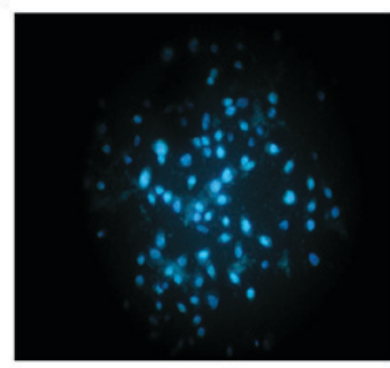

B

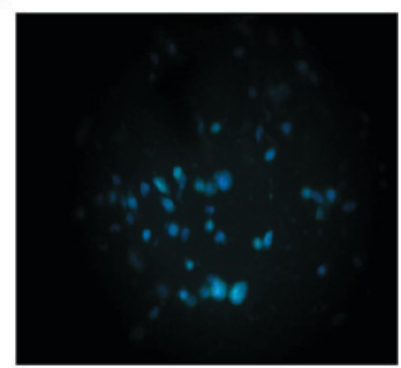

C

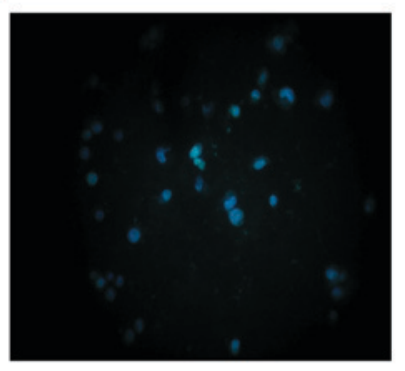

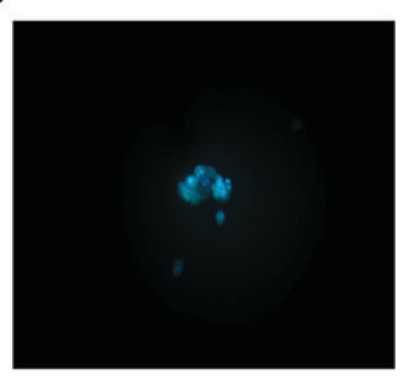

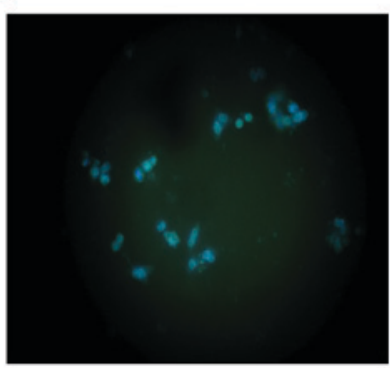

Figure 1. Morphological characterization of HepG2 cells by fluorescence detection. Cells were stained with Hoechst 33258 and observed by fluorescence microscopy (magnification, $x 400$ ). HepG2 cells were treated with (A) RPMI-1640, (B) $2.5 \mathrm{mmol} \cdot \mathrm{l}^{-1}$ cytisine, (C) $5 \mathrm{mmol} \cdot \mathrm{l}^{-1} \mathrm{cytisine}$, (D) $10 \mathrm{mmol} \cdot \mathrm{l}^{-1}$ cytisine and (E) $60 \mu \mathrm{mol} \cdot \mathrm{l}^{-1} \mathrm{HCPT}$. Apoptotic cells exhibited condensed, crescent or 'popcorn' nuclear morphology. HCPT, 10-hydroxycamptothecin.

A

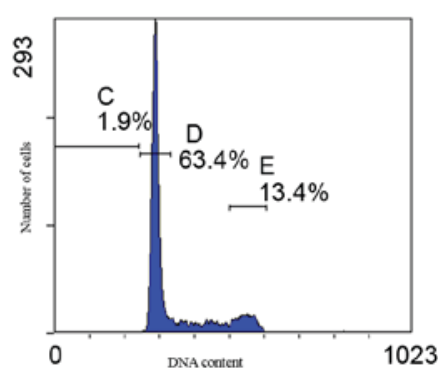

B

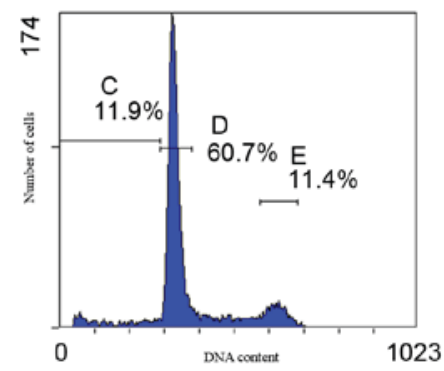

C

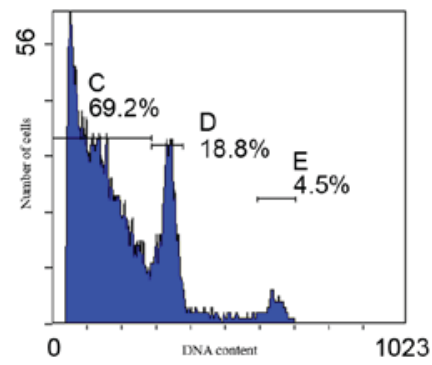

$\mathrm{D}$

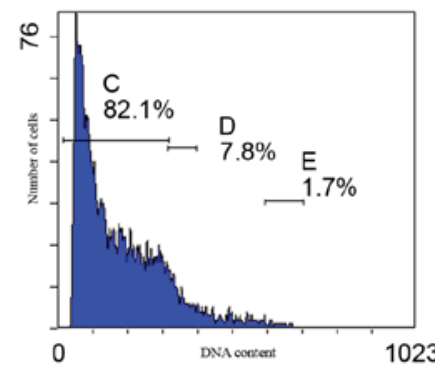

E

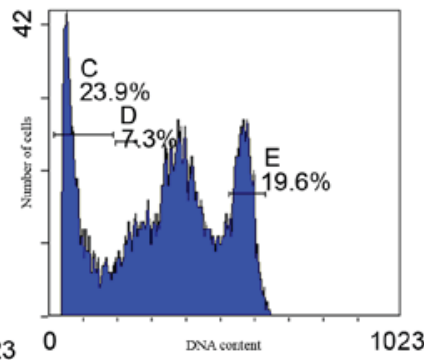

Figure 2. Apoptotic rate of HepG2 cells, as determined by flow cytometry. Cells were treated with $2.5,5$ and $10 \mathrm{mmol} \cdot \mathrm{l}^{-1}$ cytisine or $60 \mu$ mol. $1^{-1} \mathrm{HCPT}$ for $48 \mathrm{~h}$. The cells were subsequently stained with propidium iodide and analyzed using an EPICS ${ }^{\mathrm{TM}}$ XL-MCL flow cytometer. HepG2 cells treated with (A) RPMI-1640, (B) $2.5 \mathrm{mmol} \cdot \mathrm{l}^{-1}$ cytisine, (C) $5 \mathrm{mmol} \cdot \mathrm{l}^{-1}$ cytisine, (D) $10 \mathrm{mmol} \cdot \mathrm{l}^{-1}$ cytisine and (E) $60 \mu \mathrm{mol} \cdot \mathrm{l}^{-1} \mathrm{HCPT}$. In each graph, the percentages indicated by gates C-E were used to obtain the apoptotic rates presented in Table II. HCPT, 10-hydroxycamptothecin; C gate, apoptosis cells; $D$ gate, $\mathrm{G}_{1}$ cells; $\mathrm{E}$ gate, $\mathrm{G}_{2} / \mathrm{M}$ cells.

Fig. 2 and Table II). These findings indicated that cytisine induced HepG2 cell apoptosis in a dose-dependent manner.

Effects of cytisine on mitochondrial membrane potential. A decrease in fluorescence intensity was observed following cytisine treatment in a dose-dependent manner, as presented as in Fig. 3. These findings indicated that cytisine reduced mitochondrial membrane potential.

Effects of cytisine on the expression of apoptosis-associated proteins. As presented in Fig. 4, the expression levels of cytosolic Cyt-c increased in a dose-dependent manner following 
A

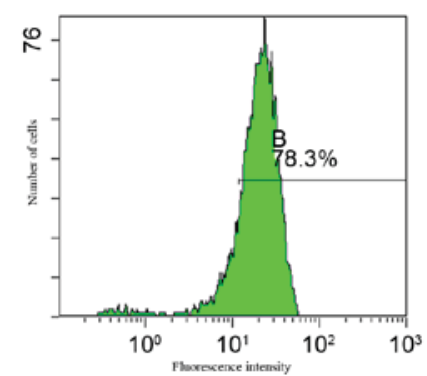

B

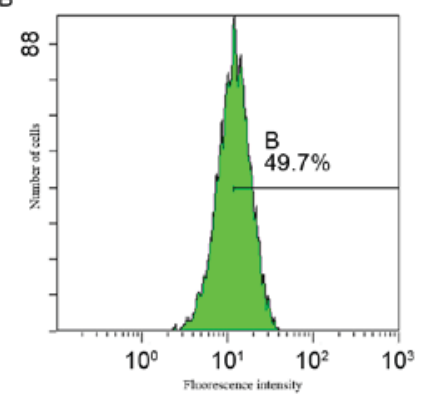

C

D

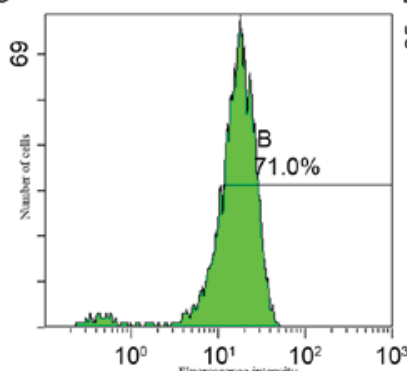

E
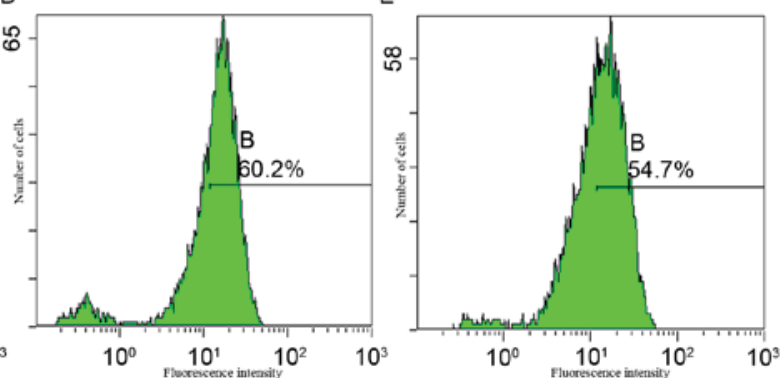

Figure 3. Mitochondrial membrane potential of HepG2 cells, as determined by flow cytometry and rhodamine 123 staining. The percentage of cells that stained positive indicates the population analyzed for rhodamine 123 . HepG2 cells treated with (A) RPMI-1640, (B) $60 \mu \mathrm{mol} \cdot \mathrm{l}^{-1} \mathrm{HCPT}$, (C) $2.5 \mathrm{mmol} \cdot \mathrm{l}^{-1} \mathrm{cytisine}$, (D) $5 \mathrm{mmol} \cdot \mathrm{l}^{-1}$ cytisine and (E) $10 \mathrm{mmol} \cdot \mathrm{l}^{-1}$ cytisine. HCPT, 10-hydroxycamptothecin.

treatment with cytisine, as compared with the untreated controls. Cytosolic Cyt-c protein expression significantly increased in the HCPT group when compared with the control group. Furthermore, cytisine significantly reduced the levels of pro-caspase-3 and significantly increased caspase-3 expression compared with in the control cells (Fig. 5). In the HCPT group, the levels of caspase-3 gradually increased with the increase in dose, and the levels of pro-caspase-3 decreased, which indicated that caspase-3 expression may be upregulated by HCPT (Fig. 5).

\section{Discussion}

Induction of apoptosis is one potential mechanism for the anticancer therapeutic effects of cytisine. MTT assays are commonly used to evaluate cell proliferation and viability. The reduction of MTT indicates cellular metabolic activity, and sites of reduction include mitochondrial and cytosolic redox reactions (30). The present study investigated the inhibitory effect of cytisine on HepG2 cell viability using the MTT assay. The results indicated that the viability of HepG2 cells was dose-dependently inhibited following exposure to cytisine.

Various types of cell death exist, including necrosis, apoptosis and autophagic cell death. Apoptosis, which is a form of programmed cell death, is a highly regulated process that permits self-degradation of cells to remove dysfunctional cells. There are two complex apoptotic pathways: The extrinsic death receptor-mediated pathway and the intrinsic mitochondria-mediated pathway $(31,32)$. In the present study, fluorescence microscopy revealed features that are characteristic of apoptosis following treatment with cytisine, confirming the ability of cytisine to induce apoptosis of HepG2 cells.
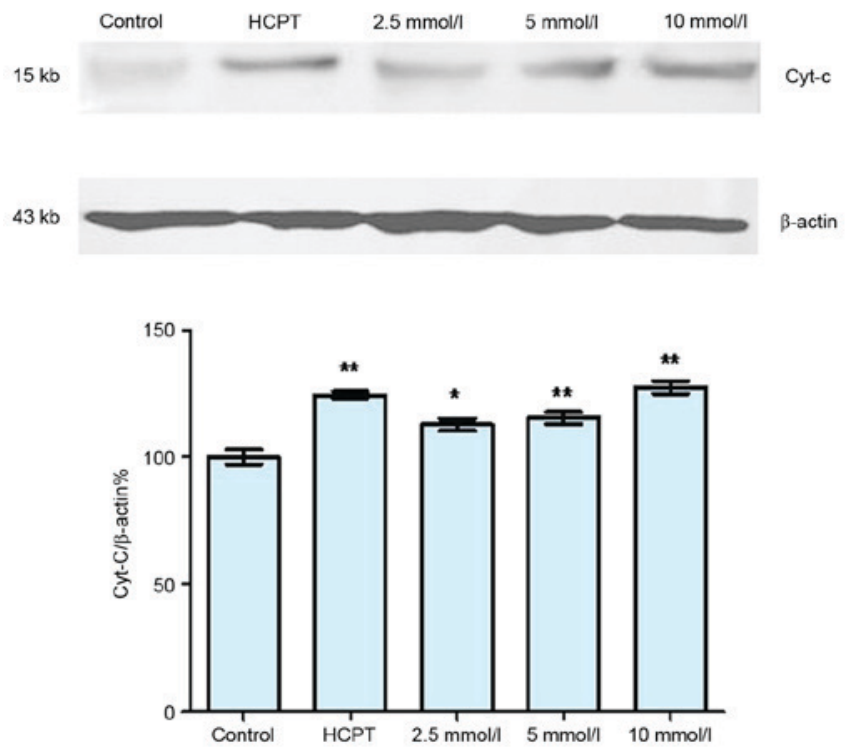

Figure 4. Effects of cytisine on the protein expression levels of Cyt-c in HepG2 cells. Cyt-c expression in the cytosol was measured following $24 \mathrm{~h}$ incubation with or without cytisine or HCPT by western blotting. " $\mathrm{P}<0.05$ and ${ }^{* *} \mathrm{P}<0.01$ vs. control. Cyt-c, cytochrome $c$; HCPT, 10-hydroxycamptothecin.

Fluorescence microscopy is a common method used for the observation of cell ultrastructure (33). To determine whether the cell membrane was disrupted, nuclear morphology was also examined using Hoechst 33258. The results indicated that cytisine induced characteristics associated with apoptosis, including shrinkage of the cytoplasm; condensation of nuclear chromatin, and its segregation into sharply delineated masses against the nuclear membrane; karyorrhexis; and the occurrence of apoptotic bodies. 

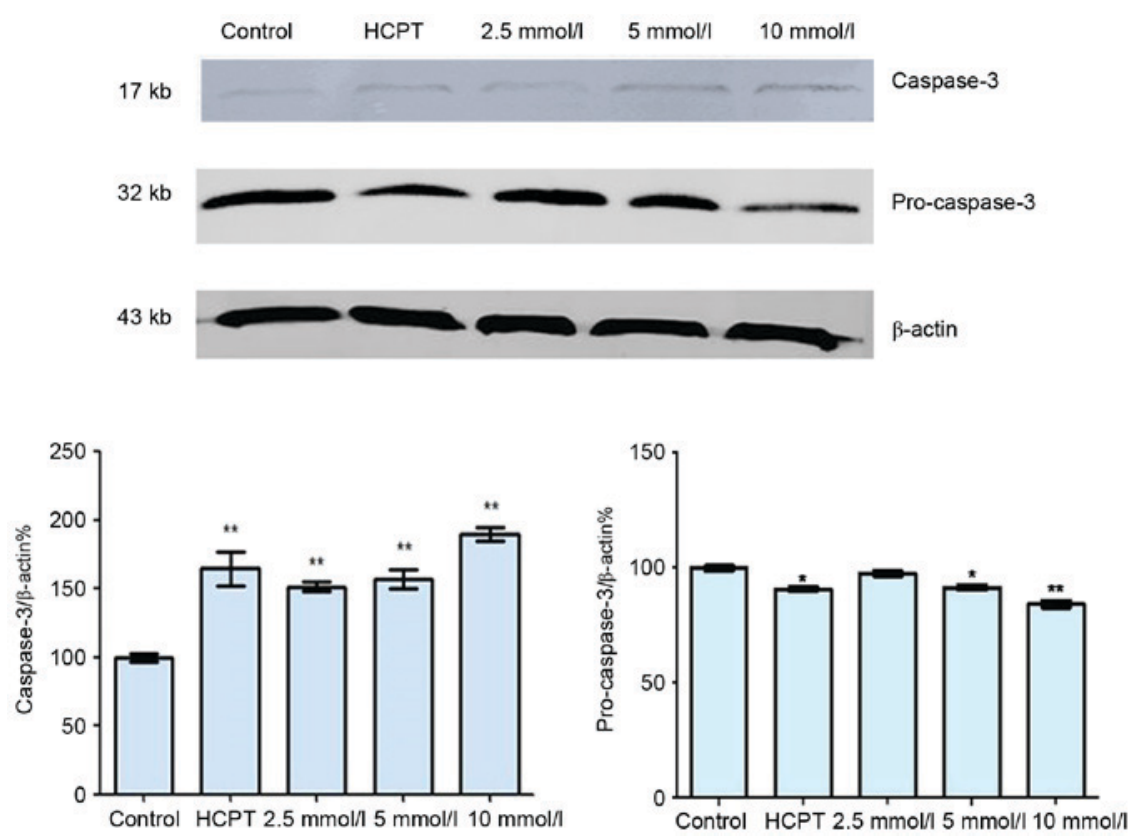

Figure 5. Effects of cytisine on the protein expression levels of pro-caspase-3 and caspase-3 in HepG2 cells. Following treatment, the fractions were resolved by SDS-PAGE, transferred onto nitrocellulose membranes, probed with specific antibodies and visualized using 3,3'-diaminobenzidine. The expression of $\beta$-actin was measured as an internal control. ${ }^{*} \mathrm{P}<0.05$ and ${ }^{* *} \mathrm{P}<0.01$ vs. control. HCPT, 10-hydroxycamptothecin.

Natural products continue to be an invaluable resource for anticancer drug discovery (34). Cytisine is a natural product isolated from plants and is a member of the quinolizidine alkaloid family. It has been used medically to aid with smoking cessation (35). However, to the best of our knowledge, no previous studies have published data concerning the effects of cytisine on hepatic carcinoma. The present study investigated the antitumor effects of cytisine on HepG2 human hepatocellular carcinoma cells and the potential mechanisms of action in vitro. The results demonstrated that cytisine may inhibit the viability and induce the apoptosis of HepG2 cells. Furthermore, cytisine-induced HepG2 apoptosis was associated with the mitochondrial pathway. The present study demonstrated by flow cytometry that cytisine may be an important apoptosis inducer in HepG2 cells, since an increase in the number of cells in the apoptotic stages was observed in vitro. After $48 \mathrm{~h}$ of treatment with $10 \mathrm{mmol} \cdot \mathrm{l}^{-1}$ cytisine, the apoptotic rate of HepG2 cells was $90.74 \pm 2.33 \%$. The rate of apoptosis appears to be dependent on the concentration of cytisine.

Cyt-c is one of the major signaling molecules involved in cellular apoptosis, and it is usually located between the inner and outer mitochondrial membranes (36). The intrinsic apoptotic pathway is a mitochondria-dependent process where a number of proapoptotic signals lead to the release of apoptogenic factors, such as Cyt-c, from the intermembrane space of the mitochondria to the cytosol (37). Once released, Cyt-c forms a complex with apoptotic peptidase activating factor 1 and deoxyadenosine triphosphate, the resulting complex is termed the apoptosome, which subsequently activates an initiator caspase. Cyt-c release leads to the activation of the caspase cascade and is therefore critical to the activation of intracellular apoptotic signals and subsequent apoptosis (38). In the present study, western blot analysis was performed to analyze the expression of apoptosis-associated proteins, in order to investigate the mechanism by which cytisine may induce apoptosis. The proteins involved in apoptosis include caspases, which are a family of proteases. Of the caspases, a previous study has demonstrated that caspase- 3 is important in the process of apoptosis, particularly in certain apoptotic signal transduction pathways (39). The protein expression of this caspase was investigated in the present study. Caspase-3, a member of the cell death protein 3 subfamily of the caspase family, has been identified downstream of the cysteine protease and is a mediator of apoptosis (40). Cytisine has been demonstrated to improve the expression of the caspase- 3 protein, suggesting that cytisine activates caspase-3. It is possible that within the cells, mitochondrial apoptosis is induced by the release of Cyt-c, which in turn leads to the activation of caspase-3. This may serve a key role in the signaling pathways leading to cell apoptosis. The results of the present study highlight the contribution of the cytosolic accumulation of Cyt-c, induced by these apoptotic stimuli, in promoting the cleavage and activity of caspase-3.

In conclusion, the results of the present study indicated that cytisine induced apoptosis of HepG2 cells in a dose-dependent manner. Therefore, cytisine may exert antitumor effects. Cytisine may induce apoptosis of tumor cells through the mitochondrial pathway, as indicated by the reduction in mitochondrial membrane potential. Following treatment with cytisine, mitochondrial permeability may increase, which may subsequently lead to mitochondrial matrix expansion, outer membrane rupture and the release of Cyt-c. Increased Cyt-c protein expression was detected in the cytosol following cytisine treatment in the present study. Increased Cyt-c release into the cytoplasm causes activation of the caspase cascade, including caspase-3. In addition, the present study reported increased levels of activated caspase- 3 , and reduced levels of inactive pro-caspase- 3 , thus indicating that cytisine may induce apoptosis via this pathway. The results of the present study provide a good experimental and theoretical basis for 
the further development and application of cytisine in clinical treatments for liver cancer.

\section{Acknowledgements}

The present study was supported in part by the Open Research Program for Key Laboratory of College of Heilongjiang Province, China (grant no. CPAT-2012003), the Natural Science Item of Department of Education of Heilongjiang Province, China (grant no. 12541205), the Innovation Talents Item of Science and Technology of Harbin city, China (grant no. 2014RFQXJ154), the Doctoral Research Project of Harbin University of Commerce (grant no. 12DL008), the Graduate Students Innovative Research Project of Harbin University of Commerce (grant no. YJSCX2015-390HSD), the 2016 Harbin University of Commerce Youth Innovation Talent Support Program (grant no. 2016QN057) and the Scientific Research Team Program of Harbin University of Commerce (grant no. 2016TD002).

\section{References}

1. Rebecca L, Kimberly D and Ahmedin J: Cancer statistics, 2016. A Can J Clin 66: 7-30, 2016.

2. Begnini KR, Moura de Leon PM, Thurow H, Schultze E, Campos VF, Martins Rodrigues F, Borsuk S, Dellagostin OA, Savegnago L, Roesch-Ely M, et al: Brazilian red propolis induces apoptosis-like cell death and decreases migration potential in bladder cancer cells. Evid Based Complement Alternat Med 2014: 639856, 2014.

3. Lin Z, Huang CF, Liu XS and Jiang J: In vitro anti-tumour activities of quinolizidine alkaloids derived from Sophora flavescens Ait. Basic Clin Pharmacol Toxicol 108: 304-309, 2011.

4. Zhou CC, Gao HB, Sun XB, Shi HB, Liu W, Yuan HN and Wang ZX: Anti-inflammatory and anti-allergic action of aloperine. Zhongguo Yao Li Xue Bao 10: 360-365, 1989.

5. Zhang L, Zheng Y, Deng H, Liang L and Peng J: Aloperine induces G2/M phase cell cycle arrest and apoptosis in HCT116 human colon cancer cells. Int J Mol Med 33: 1613-1620, 2014.

6. Du M, Zhang J, Xu D, Li W, Liu J and Liu F: Inhibition of pro-collagen I expression by oxymatrine in hepatic stellate cells is mediated via nuclear translocation of Y-box binding protein 1. Mol Med Rep 12: 8101-8106, 2015.

7. Liang L, Wang XY, Zhang XH, Ji B, Yan HC, Deng HZ and Wu XR: Sophoridine exerts an anti-colorectal carcinoma effect through apoptosis induction in vitro and in vivo. Life Sci 91: 1295-1303, 2012.

8. Wang WX, Sun ZH, Chen HM, Xu BN and Wang FY: Role and mechanism of Sophoridine on proliferation inhibition in human glioma U87MG cell line. Int J Clin Exp Med 8: 464-471, 2015.

9. Zhu YY, Huang HY and Wu YL: Anticancer and apoptotic activities of oleanolic acid are mediated through cell cycle arrest and disruption of mitochondrial membrane potential in HepG2 human hepatocellular carcinoma cells. Mol Med Rep 12: 5012-5018, 2015

10. Luo X, Budihardjo I, Zou H, Slaughter C and Wang X: Bid, a $\mathrm{Bcl} 2$ interacting protein, mediates cytochrome $\mathrm{c}$ release from mitochondria in response to activation of cell surface death receptors. Cell 94: 481-490, 1998.

11. Marcaurelle LA, Johannes C, Yohannes D, Tillotson BP and Mann D: Diversity-oriented synthesis of a cytisine-inspired pyridone library leading to the discovery of novel inhibitors of Bcl-2. Bioorg Med Chem Lett 19: 2500-2503, 2009.

12. Chellappan SK, Xiao Y, Tueckmantel W, Kellar KJ and Kozikowski AP: Synthesis and pharmacological evaluation of novel 9- and 10-substituted cytisine derivatives. Nicotinic ligands of enhanced subtype selectivity. J Med Chem 49: 2673-2676, 2006.

13. Muslim NS, Ng KW, Itam A, Nassa ZD, Ismail Z and Abdul Majid AMS: Evaluation of cytotoxic, anti-angiogenic and antioxidant properties of standardized extracts of strobilanthes crispus leaves. Int J Pharmacol 6: 591-599, 2010.
14. Harpsøe K, Hald H, Timmermann DB, Jensen ML, Dyhring T, Nielsen EØ, Peters D, Balle T, Gajhede M, Kastrup JS and Ahring PK: Molecular determinants of subtype-selective efficacies of cytisine and the novel compound NS3861 at heteromeric nicotinic acetylcholine receptors. J Biol Chem 288: 2559-2570, 2013.

15. Wang H, Yang S, Zhou H, Sun M, Du L, Wei M, Luo M, Huang J, Deng H, Feng Y, et al: Aloperine executes antitumor effects against multiple myeloma through dual apoptotic mechanisms. J Hematol Oncol 8: 26, 2015.

16. Sciamanna MA, Griesmann GE, Williams CL and Lennon VA: Nicotinic acetylcholine receptors of muscle and neuronal (alpha7) types coexpressed in a small cell lung carcinoma. J Neurochem 69: 2302-2311, 1997.

17. Wang J, Fu XQ, Lei WL, Wang T, Sheng AL and Luo ZG: Nuclear factor kappa в controls acetylcholine receptor clustering at the neuromuscular junction. J Neurosci 30: 11104-11113, 2010.

18. Chacko S and Samanta S: 'Hepatocellular carcinoma: A life-threatening disease'. Biomed Pharmacother 84: 1679-1688, 2016.

19. Dickinson $\mathrm{BC}$ and Chang $\mathrm{CJ}$ : Chemistry and biology of reactive oxygen species in signaling or stress responses. Nat Chem Biol 7: 504-511, 2011.

20. Muchmore SW, Sattler M, Liang H, Meadows RP, Harlan JE, Yoon HS, Nettesheim D, Chang BS, Thompson CB, Wong SL, et al: X-ray and NMR structure of human Bcl-xL, an inhibitor of programmed cell death. Nature 381: 335-341, 1996.

21. Carmichael J, DeGraff WG, Gazdar AF, Minna JD and Mitchell JB: Evaluation of a tetrazolium-based semiautomated colorimetric assay: Assessment of chemosensitivity testing. Cancer Res 47: 936-942, 1987.

22. Araki T, Yamamoto A and Yamada M: Accurate determination of DNA content in single cell nuclei stained with Hoechst 33258 fluorochrome at high salt concentration. Histochemistry 87: 331-338, 1987.

23. Holmquist G: Hoechst 33258 fluorescent staining of Drosophila chromosomes. Chromosoma 49: 333-356, 1975.

24. Wyllie AH, Morris RG, Smith AL and Dunlop D: Chromatin cleavage in apoptosis: Association with condensed chromatin morphology and dependence on macromolecular synthesis. J Pathol 142: 67-77, 1984.

25. Gong J, Traganos F and Darzynkiewicz Z: A selective procedure for DNA extraction from apoptotic cells applicable for gel electrophoresis and flow cytometry. Anal Biochem 218: 314-319, 1994.

26. Nicoletti I, Migliorati G, Pagliacci MC, Grignani F and Riccardi C: A rapid simple method for measuring thymocyte apoptosis by propidium iodide staining and flow cytometry. J Immunol Methods 139: 271-279, 1991

27. Basiji DA, Ortyn WE, Liang L, Venkatachalam V and Morrissey P: Cellular image analysis and imaging by flow cytometry. Clin Lab Med 27: 653-670, viii, 2007.

28. Scaduto RC Jr and Grotyohann LW: Measurement of mitochondrial membrane potential using fluorescent rhodamine derivatives. Biophys J 76: 469-477, 1999.

29. Ashley RL, Militoni J, Lee F, Nahmias A and Corey L: Comparison of Western blot (immunoblot) and glycoprotein G-specific immunodot enzyme assay for detecting antibodies to herpes simplex virus types 1 and 2 in human sera. J Clin Microbiol 26: 662-667, 1988.

30. Zhang H, Xiong Z, Wang J, Zhang SS, Lei L, Yang L and Zhang Z: Glucagon-like peptide-1 protects cardiomyocytes from advanced oxidation protein product-induced apoptosis via the PI3K/Akt/Bad signaling pathway. Mol Med Rep 13: 1593-1601, 2016.

31. Kim KN, Ham YM, Moon JY, Kim MJ, Kim DS, Lee WJ, Lee NH and Hyun CG: In vitro cytotoxic activity of sargassum thunbergii and dictyopteris divaricata (Jeju Seaweeds) on the HL-60 tumour cell line. Int J Pharmacol 5: 298-306, 2009.

32. Oh HL, Lee DK, Lim H and Lee CH: HY253, a novel decahydrofluorene analog, from Aralia continentalis, induces cell cycle arrest at the G1 phase and Cyt-C-mediated apoptosis in human lung cancer A549 cells. J Ethnopharmacol 129: 135-139, 2010.

33. Darzynkiewicz Z, Juan G, Li X, Gorczyca W, Murakami T and Traganos F: Cytometry in cell necrobiology: Analysis of apoptosis and accidental cell death (necrosis). Cytom 27: 1-20, 1997.

34. Hwang MW and Kim BJ: Apoptotic effects and involvement of TRPM7 channels of the traditional herbal medicine, dangkwisoo-san in gastric cancer cells. Int J Pharmacol 10: 398-405, 2014. 
35. Gazaliev AM, Zhurinov MZ and Tuleuov BI: Isolation, analysis, biosynthesis, and modification of the alkaloid cytisine. Chem Nat Com 27: 259-269, 1991.

36. Scorrano L: Opening the doors to cytochrome c: Changes in mitochondrial shape and apoptosis. Int J Biochem Cell Biol 41: 1875-1883, 2009.

37. Rouhollahi E, Zorofchian Moghadamtousi S, Paydar M, Fadaeinasab M, Zahedifard M, Hajrezaie M, Ahmed Hamdi OA Looi CY, Abdulla MA, Awang K and Mohamed Z: Inhibitory effect of Curcuma purpurascens BI. rhizome on HT-29 colon cancer cells through mitochondrial-dependent apoptosis pathway. BMC Complement Altern Med 15: 15, 2015.
38. Philchenkov AA: Caspases as regulators of apoptosis and other cell functions. Biochem (Mosc) 68: 365-376, 2003.

39. Riedl SJ and Shi Y: Molecular mechanisms of caspase regulation during apoptosis. Nat Rev Mol Cell Bio 5: 897-907, 2004.

40. Alnemri ES, Livingston DJ, Nicholson DW, Salvesen G, Thornberry NA, Wong WW and Yuan J: Human ICE/CED-3 protease nomenclature. Cell 87: 171, 1996. 